\title{
ICE-SHELF RESPONSE TO ICE-STREAM DISCHARGE FLUCTUATIONS: III. THE EFFECTS OF ICE-STREAM IMBALANCE ON THE ROSS ICE SHELF, ANTARCTICA
}

\author{
By Douglas R. Mácayeal
}

(Department of Geophysical Sciences, University of Chicago, Chicago, Illinois 60637, U.S.A.)

Abstract. A numerical simulation of the Ross Ice Shelf, Antarctica, in which discharge from Ice Streams A-E is changed suddenly between extreme states, is used to investigate ice-shelf thickness and flow anomalies generated by ice-stream transience. At one extreme, ice-stream discharge rates specified as model boundary conditions are balanced individually with snow accumulation in the ice-stream catchment areas. At the other, discharge rates are fixed at current observed values which widely depart from mass balance. The simulated ice-shelf evolution between initial and final steady states suggests that ice-thickness and velocity fields adjust to new ice-stream conditions over a relatively short time span (approximately 500 years). In contrast, transitory geometrics of medial moraines and relict-crevasse bands persist over a longer time span (up to 2000 years). Contortions of medial moraines and relict-crevasse bands thus may provide a useful long-term history of past ice-stream activity. The past stoppage of Ice Stream C, for example, should be evident today in some medial moraine trajectories even if the stoppage occurred over 1000 years ago. Ice-shelf thickness fluctuations induced by ice-stream activity are generally restricted to the neighborhood of the grounding line. These fluctuations may constitute a trigger for ice-rise formation near ice-stream outlets.

\section{INTRODUCTION}

Temporal variability may be an intrinsic property of ice-stream discharge. This proposition is motivated by observations of regional mass imbalance and abandoned ice-stream channels in the West Antarctic ice-sheet drainage system (Shabtaie and Bentley, 1987), and by direct measurement of velocity changes over the last decade at the mouth of Ice Stream B (Stephenson and Bindschadler, 1988). The cause of this variability is unknown, but it may stem from the interplay of several physical systems that affect ice-stream flow. Subglacial sediment conditions, subglacial hydrology, ice-rise formation, ice-stream piracy, and regional climate variations, for example, can each potentially contribute to an explanation of ice-stream transience.

Adequate characterization of ice-shelf response to ice-stream fluctuation is essential in three respects. First, ice-shelf/ice-stream coupling may determine the amplitude and time-scale of ice-stream discharge oscillations. Ice-thickness fluctuations generated by ice-stream discharge, for example; may trigger ice-rise formation. These ice rises, in turn, may increase ice-shelf back pressure and provide a negative feed-back on ice-stream discharge. Secondly, early detection of ice-shelf change in response to $\mathrm{CO}_{2}$ warming may depend on the ability to differentiate the effects of climate from the effects of ice streams. Thirdly, synergy between ice-stream transience and external climate forcing may introduce an unpredictable element to ice-sheet behavior.

Here I present an assessment of ice-thickness anomalies and other disturbances on the Ross Ice Shelf caused by ice-stream transience. This assessment represents the third in a series of investigations concerning ice-shelf response to ice-stream forcing (MacAyeal and Barcilon, 1988; MacAyeal and Lange, 1988). The goal of this study is to estimate the range of ice-shelf variation associated with the current, observed mass imbalance of Ice Streams A-E. To achieve this goal, a time-dependent numerical simulation of the Ross Ice Shelf (Fig. 1) subject to variable ice-stream discharge is performed using methods described by MacAyeal and Lange (1988) and by MacAyeal and others (1988). Changes in ice thickness, velocity, and relict-crevasse band trajectories are analyzed to determine characteristic amplitudes and time-scales, and to motivate future observations.

\section{METHODS}

The history of ice-stream events that have affected the Ross Ice Shelf is complex and largely unknown. Progress can be made, however, by considering the extremes of possible ice-stream discharge states. This study examines the range of ice-shelf configurations that can be supported by two discharge extremes relevant to current mass-balance observations. At one extreme, the discharge of each ice stream is balanced with current snow accumulation in the associated catchment area. At the other, ice-stream discharge is at its current, unbalanced state. These extremes are listed in Table $\mathrm{I}$, and are derived from field measurements described by Shabtaie and Bentley (1987).

To assess the range of ice-thickness and flow anomalies on the Ross Ice Shelf, a finite-element model described by MacAyeal and Lange (1988) is used to solve the time-dependent mass- and stress-balance equations. Ice-stream velocity and mass flux described in Table I are applied as boundary conditions on the model. Realistic ice-shelf geometry is incorporated in the finite-element domain (Fig. 1), but is assumed to be unchanged with time. This assumption excludes possible movement of grounding lines and ice-rise formation that could accompany changes in ice-stream discharge, but is necessary to isolate the effects of ice-stream forcing. The ice-hardness parameter used in the flow law is assumed constant $\left(1.6 \times 10^{8} \mathrm{~Pa} \mathrm{~s}^{1 / 3}\right)$ at the value implied by the observed temperature/depth profile at J9 (Thomas and MacAyeal, 1982). Surface accumulation is assumed constant at $0.10 \mathrm{~m} / \mathrm{a}$, and basal melting is assumed nil.

The ice-shelf model was run for sufficiently many time steps holding ice-stream discharge at balanced values to achieve a steady state. This steady state was then used as an initial condition for a run in which ice-stream discharge was instantaneously switched to its current, observed state (Table I). The second model run was stopped when a new steady-state was achieved. Comparisons between the initial and final steady states, and analysis of the transition between the two, form the results presented in this paper.

Relict-crevasse bands and medial moraine trajectories are observable by radio echo-sounding (Jezek, 1984; Shabtaie and Bentley, 1987), and thus constitute important flow tracers useful in comparisons between model and data. The 
MacAyeal: Ice-shelf responses: III
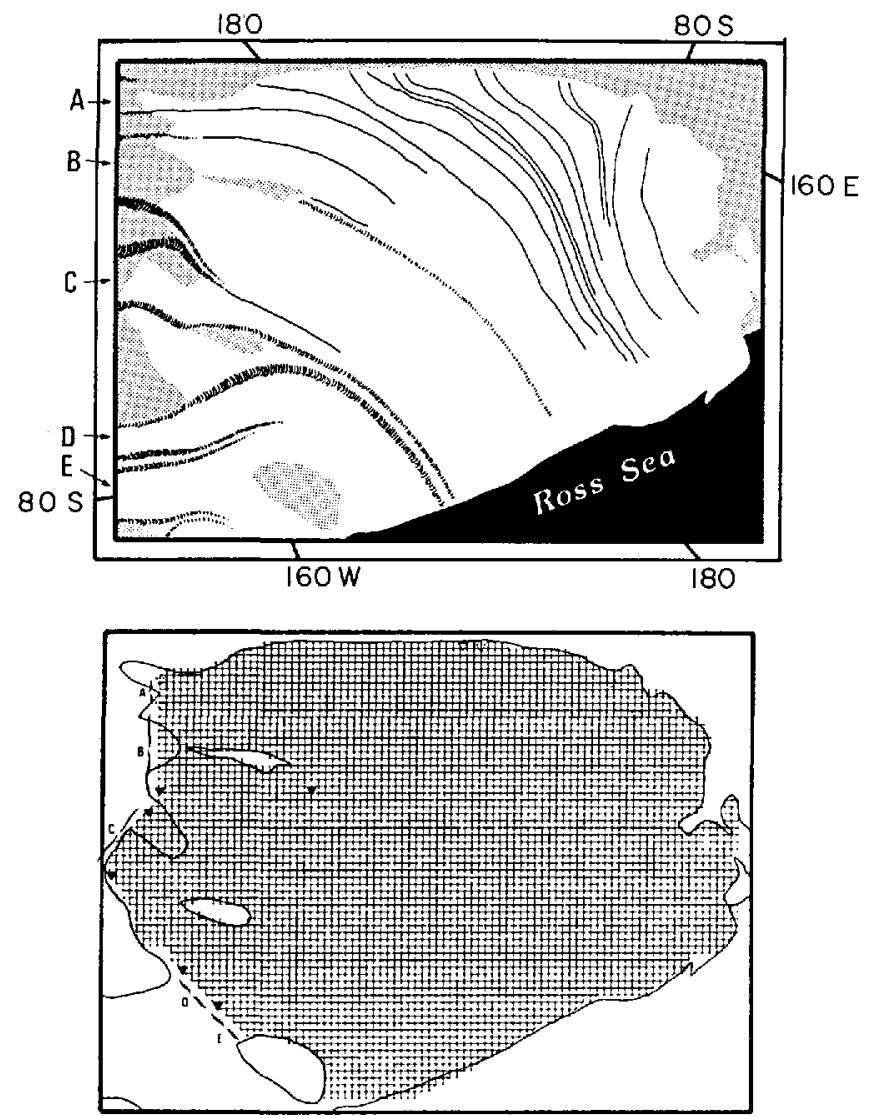

Fig. 1. Upper. Ross Ice Shelf. Stippled areas correspond to grounded ice sheet or ice-free mountain range. Outlets of Ice Streams $A-E$ are indicated in the left margin. Relict-crevasse band and medial moraine trajectories observed by Shabtaie and Bentley (1987) and Jezek (1984) are indicated by thin lines or cross-hatched bands. Lower. The finite-element representation of the Ross Ice Shelf. Mesh resolution is $10 \mathrm{~km}$. Triangles denote positions where imaginary tracer particles were introduced into the simulated flow as representations of medial moraines and relict-crevasse bands. Solid triangles denote relict-crevasse band origins, and open triangles denote medial moraine origins. Finite-element mesh points where ice-stream velocity and volume flux were specified as boundary conditions are indicated by brackets. To reduce the size of the mesh, discharge from Ice Streams $D$ and $E$ was specified as a boundary condition on a boundary extending from Siple Dome to the tip of Roosevelt Island. Only half of the total discharge from Ice Stream $E$ is thus assumed to pass through this boundary. The other half is assumed to pass east of Roosevelt Island.

evolution of these flow tracers on the Ross Ice Shelf are simulated following the procedure described by MacAyeal and others (1988). While not commonly used as indicators of ice-flow variability in large-scale ice shelves, medial moraine contortions have been used as a means of identifying surging valley glaciers (Meier and Post, 1969). Imaginary tracer particles representing discrete relict crevasses (or moraine material) are inserted periodically into the simulated flow at fixed locations corresponding to where the present crevasse bands or medial moraines (shown in Figure 1) enter the ice shelf. These particles drift freely

Fig. 2. Upper. Ice-shelf thickness anomaly envelope representing the total thickness change between the current and balanced ice-stream discharge states described in Table I. Contour interval is $20 \mathrm{~m}$. and contours having negative values are drawn with broken lines. Lower. Ice-shelf velocity anomaly envelope. Contour interval is $100 \mathrm{~m} / \mathrm{a}$, and contours having negative values are drawn with broken lines.
TABLE I. ICE-STREAM DISCHARGE SCENARIOS*

Volume flux

$\begin{array}{lccc}\text { Ice stream } & \text { Balanced } & \text { Current } & \text { Difference } \\ & \mathrm{km}^{3} / \text { year } & \mathrm{km}^{3} / \text { year } & \mathrm{km}^{3} / \text { year } \\ & & & \\ \text { A } & 8.0 & 13.2 & 5.2 \\ \text { B } & 17.3 & 37.3 & 20.0 \\ \text { C } & 18.6 & 0.5 & -18.1 \\ \mathrm{D}^{+} & 15.2 & 22.5 & -7.3 \\ \mathrm{E}^{+} & 22.3 & 26.2 & 3.9\end{array}$

Velocity

Ice stream Balanced Current Difference

$\begin{array}{lccc} & \text { m/year } & \text { m/year } & \mathrm{m} / \text { year } \\ \text { A } & & & \\ \text { B(B1-B2) } & 189-215 & 499 & 158 \\ \text { C }^{\ddagger} & 500 & 407-464 & 218-249 \\ \text { D } & 312 & 5 & -495 \\ \text { E } & 272 & 462 & 150 \\ & 2720 & 48\end{array}$

*Data source: Shabtaie and Bentley (1987). Ice influx was also specified at mesh points corresponding to Byrd Glacier $\left(16 \mathrm{~km}^{3} /\right.$ year, $615 \mathrm{~m} /$ year $)$, Beardmore Glacier $\left(9 \mathrm{~km}^{3} /\right.$ year, $462 \mathrm{~m} /$ year), Liv Glacier $\left(2 \mathrm{~km}^{3} /\right.$ year, $285 \mathrm{~m} /$ year $)$, Mulock Glacier $\left(3 \mathrm{~km}^{3} /\right.$ year, $222 \mathrm{~m} /$ year $)$, Nimrod Glacier $\left(3 \mathrm{~km}^{3} /\right.$ year, $200 \mathrm{~m} /$ year $)$, and Shackleton Glacier $\left(1 \mathrm{~km}^{3} /\right.$ year, $182 \mathrm{~m} /$ year). $\mathrm{B} 1$ is the southern half and $\mathrm{B} 2$ is the northern half of Ice Stream B.

${ }^{+} 50 \%$ of the discharge of Ice Stream $E$ is assumed to enter the part of the Ross Ice Shelf modeled.

${ }^{\mp}$ The velocity of Ice Stream $C$ when in balance with snow accumulation is assumed to be $500 \mathrm{~m} /$ year.

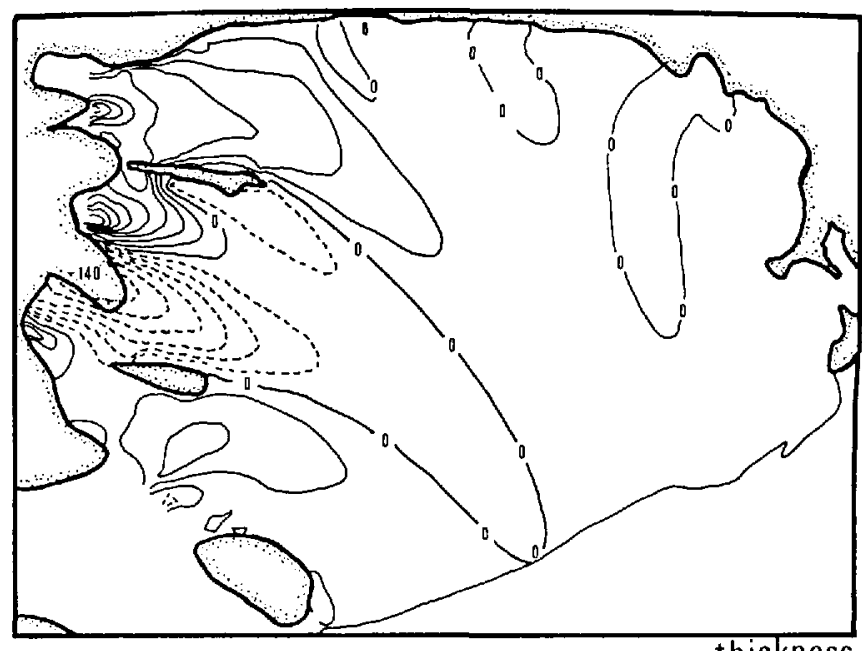

thickness

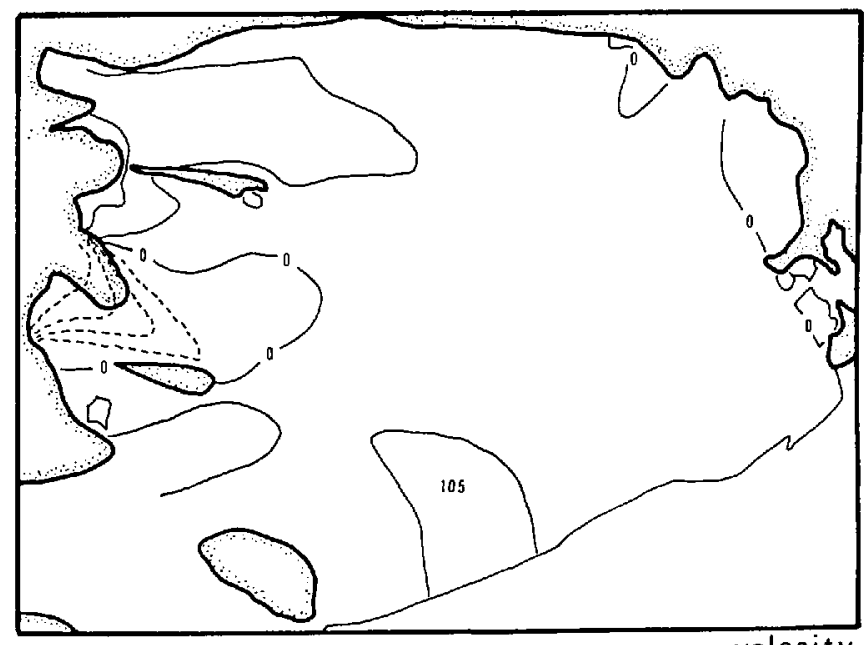

velocity

anomaly 


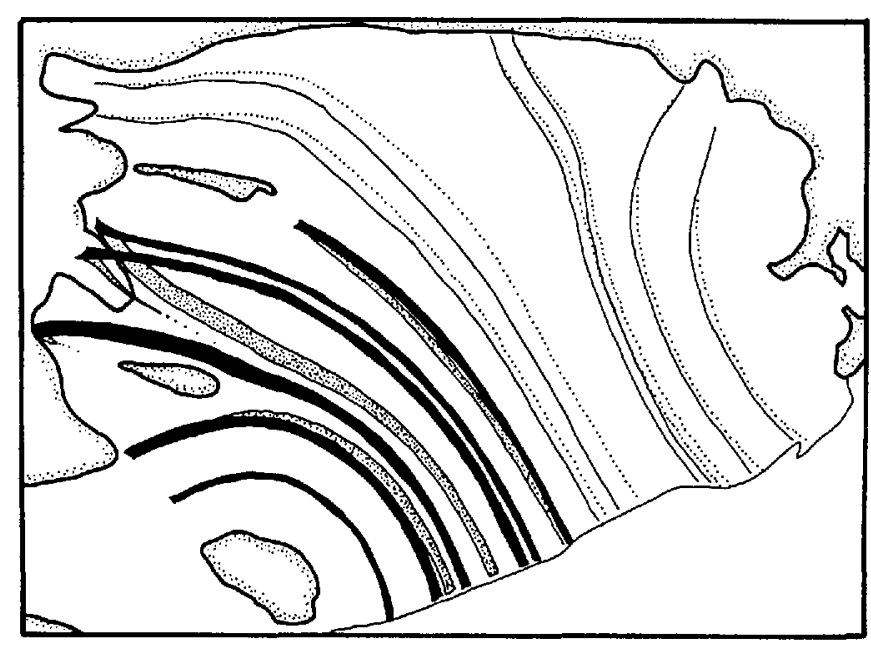

Fig. 3. Simulated relict-crevasse band and medial moraine trajectories associated with steady-state ice-shelf conditions in balance with the two ice-stream discharge configurations in Table I. Trajectories associated with balanced discharge are drawn as black bands or thin solid lines. Trajectories associated with current. imbalanced discharge are drawn as stippled bands or dotted lines. The latter trajectories may be compared with the observed trajectories shown in Figure 1. Origins of the trajectories and their relationship with the positions of the ice-stream outlets are also shown in Figure 1.

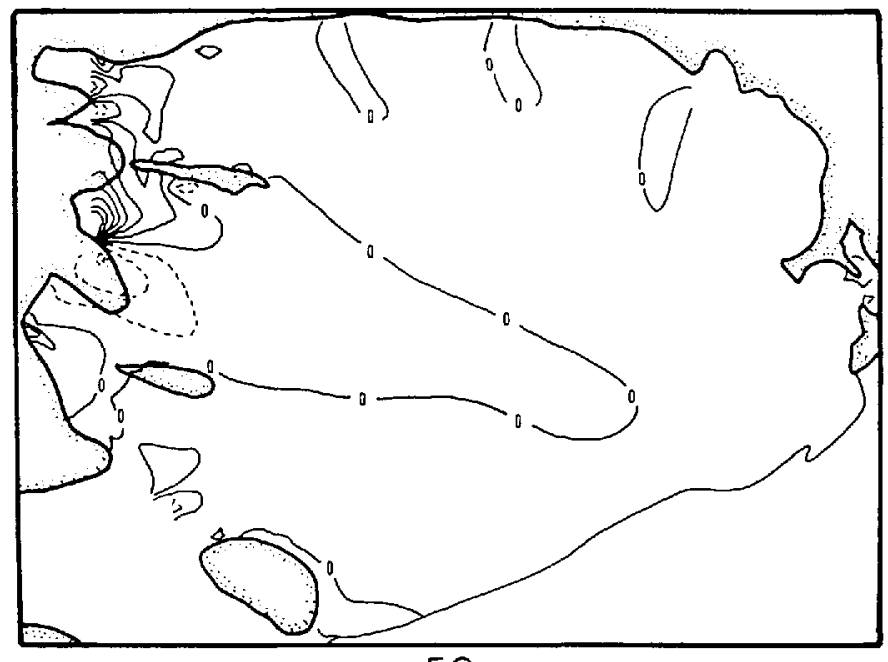

500

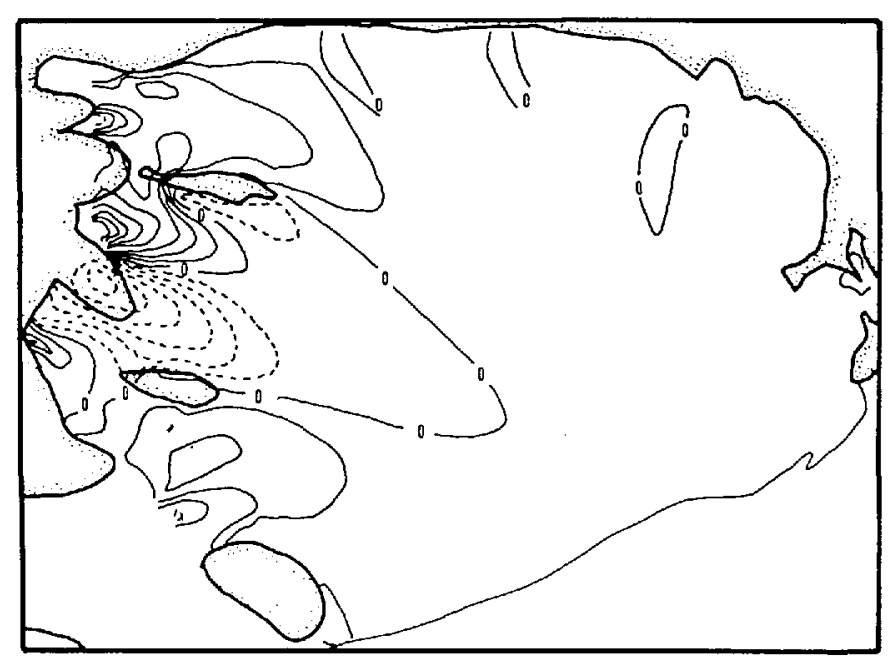

$250 a$ with the simulated flow. The curve formed by connecting particles originating from a common source constitutes the simulated crevasse band or medial moraine trajectory. In some circumstances, observed relict-crevasse bands have a large transverse width determined by the width of the crevassed shear margins of the ice streams. To simulate these features, the trajectories of the two edges of the relict crevasse band are monitored separately.

\section{RESULTS}

As stated previously, it is not practical to describe ice-shelf thickness and flow fluctuations associated with all plausible ice-stream histories. It is practical, however, to determine bounds on fluctuations that would apply to an arbitrary ice-stream history subject to the constraint that discharge rates fluctuate between the two extremes defined in Table I. Differences between the initial and final steady states produced by the model under the forcing conditions described above thus define amplitude envelopes for ice-thickness and velocity anomalies generated by more complex ice-stream histories. The term anomaly is used here to denote the deviation of a given field from its long-term average.

As seen in Figure 2, thickness difference between the initial and final steady states is greatest at the ice-stream outlets, and decay down-stream within approximately $150 \mathrm{~km}$. Thickness anomalies forced by diverse ice-stream discharge events thus are bounded by this thickness difference. Large-scale thickness anomalies are lobe-shaped and extend down-stream of the outlets along flow lines.
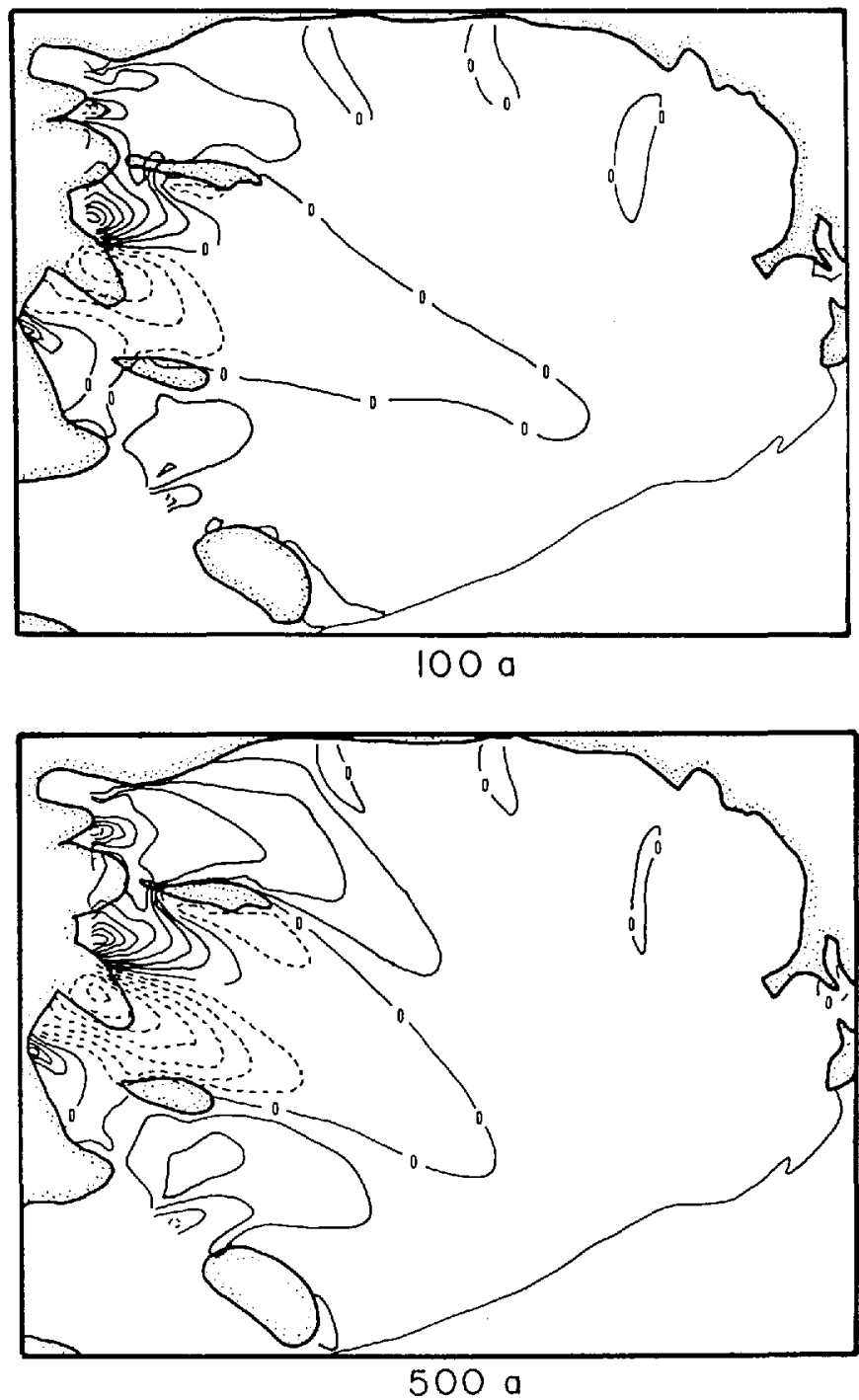

Fig. 4. Net ice-thickness change at various times following a sudden switch of ice-stream discharge between values described in Table I. Contour interval is $20 \mathrm{~m}$ and negative contours are denoted by broken lines. 
Thickness anomaly immediately down-stream of a given ice-stream outlet is directly proportional to ice-stream discharge fluctuation. Thickness anomalies in some smallscale regions, such as in the wake of the Crary Ice Rise, can be inversely proportional to the discharge fluctuation of a nearby ice stream. This inverse proportionality results from increased horizontal spreading down-stream of obstructions and within narrow rift zones adjacent to ice-stream outlets.

Spatial patterns of ice-shelf velocity anomalies, also shown in Figure 2, are qualitatively different from those of thickness anomalies. Large amplitudes are not confined to the neighborhood of ice-stream outlets. Near the ice front, for example, velocity anomalies are comparable in magnitude to those near the grounding line.

Differences between relict-crevasse band and medial moraine trajectories associated with the initial and final steady states described above are shown in Figure 3. The greatest difference occurs for the relict-crevasse band generated at the northern margin of Ice Stream B. This band moves laterally, by up to $100 \mathrm{~km}$, in response to acceleration of Ice Stream B and stoppage of Ice Stream C (Table I). Trajectories least affected by the ice-stream discharge scenario examined here lie in the western half of the ice shelf. Model simulations not discussed here suggest that snow-accumulation and basal-melting rates constitute a more effective control on these trajectories than ice-stream or outlet-glacier discharge.

Time-dependent evolution from the initial to the final steady states described above was monitored to determine the temporal and spatial characteristics of transient adjustment. Net thickness changes at 50, 100, 250, and $500 \mathrm{a}$ after the instantaneous change in ice-stream discharge are shown in Figure 4. The instantaneous trajectory for a relict-crevasse band emanating from Ice Stream $B$ is shown at 0 (the initial steady state), 250,500, 1000, and 3000 a (the final steady state) in Figure 5.

Comparison of Figures 4 and 5 indicates that thickness adjustment is completed more rapidly than adjustment of relict-crevasse bands and medial moraine trajectories. Thinning at the mouth of Ice Stream $C$, for example, is approximately $85 \%$ complete after $500 \mathrm{a}$. In contrast, $500 \mathrm{a}$ are sufficient for establishment of the new geometry along only $20 \%$ of the relict-crevasse band extending from the northern edge of Ice Stream B. This contrast is explained by the confinement of ice-thickness anomalies within a short distance of the ice-stream outlets. Due to this confinement, a short time span is required for individual ice parcels to traverse the region of strongest thickness change. Thickness change thus can be completed well before

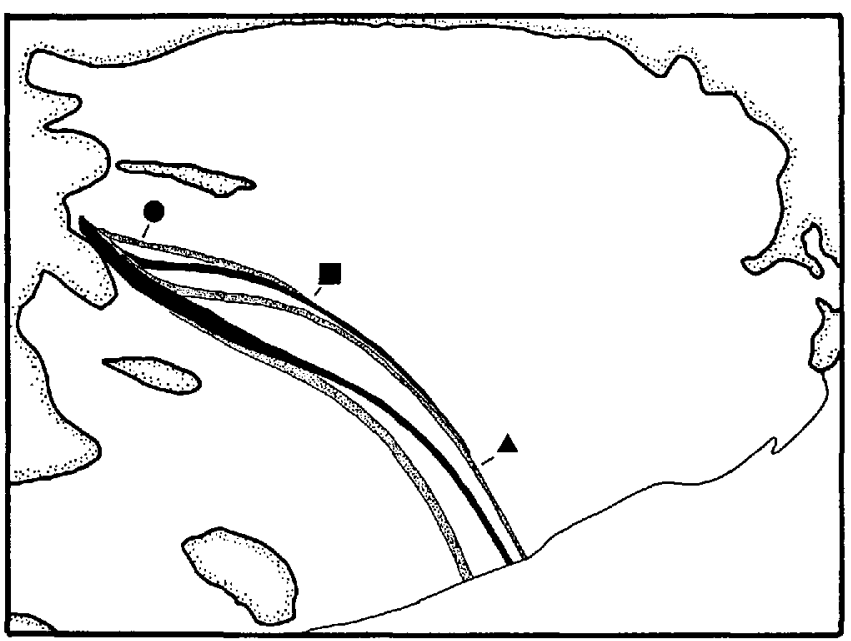

Fig. 5. Evolution of a relict-crevasse band after the sudden change of ice-stream discharge. The outermost bands (stippled) represent the initial (upper) and final (lower) configurations. Intermediate configurations are shown for 250. 500, and 1000a. Symbols denole approximate positions where deviations between the tangents to the instantaneous trajectory and the local velocity vectors are compared. Results of this comparison are shown in Figure 6. ice parcels have migrated the full longitudinal span of the ice shelf. In contrast, relict-crevasse bands and medial moraines can change in response to ice-stream variation over the full span of the ice shelf. Thus, more time is required for relict-crevasse elements or medial moraine material to traverse the region of strongest flow-line change.

The nature of relict-crevasse band and medial moraine contortion provides an excellent opportunity to deduce past ice-shelf behavior from simple observations of present conditions. This is because: (1) deviation between the tangents to a relict-crevasse band trajectory, and local velocity vectors can immediately indicate non-steady flow (Batchelor, 1967), and (2) such deviations are commonly observed on the Ross Ice Shelf (Jezek, 1984). Time histories of the deviations computed at three points of the trajectory emanating from Ice Stream B are shown in Figure 6. The

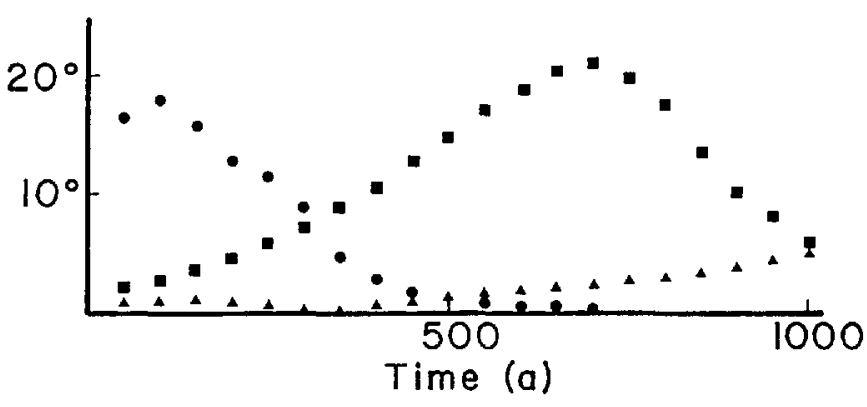

Fig. 6. Deviations between tangents to the relict-crevasse band trajectory (at three positions shown in Figure 5) and instantaneous local velocity vectors as functions of time. The time series for the position farthest up-stream is indicated by solid circles; for the middle position by solid squares; and for the position farthest down-stream by solid triangles, 500 years are sufficient for the deviation at the most up-stream point to reach maximum and return to zero. Time spans in excess of 1000 years are required for points farther down-stream to complete their adjustment.

most up-stream point completes its adjustment to new ice-stream conditions rapidly within the initial $500 \mathrm{a}$. Points further down-stream achieve maximum deviations between tangent and velocity vector after several hundred years, and take substantially longer to return to zero deviation.

Shabtaie and Bentley (1987) have estimated, on the basis of crevasse burial, a 250 year time period since shut-down of Ice Stream C. In view of the results shown in Figures 5 and 6 , current deviations between trajectory tangents and local velocity vectors should be maximized approximately $200 \mathrm{~km}$ down-stream of the grounding line. Unfortunately, the relict-crevasse band trajectory in this region has not been mapped.

\section{CONCLUSIONS}

Given that the range and frequency of ice-stream discharge fluctuations are unknown, only general characteristics of ice-shelf response can be established with certainty. Based on the simple ice-stream change scenario considered here (instantaneous switch from balanced to current discharge), the following conclusions can be drawn:

1. Ice-thickness changes associated with ice-stream fluctuations are generally greatest at the grounding line of the ice stream and decay down-stream with a length scale of approximately $150 \mathrm{~km}$. Velocity changes are more widespread. These spatial characteristics suggest that the response to climate change can be differentiated from background ice-shelf variability by examining the spatial correlation of observed ice-shelf thickness and velocity changes.

2. Small-scale thickness anomalies can be inversely related to ice-stream discharge. Acceleration of Ice Stream $B$, for example, produces thinning in the wake of Crary Ice Rise. 
3. Relict-crevasse band and medial moraine trajectories are excellent indicators of ice-shelf transience. A similar result was proposed 20 years ago by Meier and Post (1969) in the context of surging valley glaciers. As a result of the current study, strong changes in relict-crevasse bands on the Ross Ice Shelf are shown to result from low-frequency changes in some of the West Antarctic ice streams. Deviations between such trajectories and instantaneous stream lines can exceed $20^{\circ}$ and persist for thousands of years after an instantaneous change in ice-stream forcing. It is thus advantageous, from the standpoint of deducing past ice-stream history, to concentrate future ice-shelf velocity measurements along such trajectories.

4. When subject to ice-stream fluctuation, relict-crevasse band and medial moraine trajectories take longer to adjust than ice thickness. This difference occurs because ice-thickness changes are confined within a small distance of the grounding line.

5. If the apparent shut-down of Ice Stream $C$ occurred 250 years ago (Shabtaie and Bentley, 1987), thinning in excess of $100 \mathrm{~m}$ should now be complete near the outlet of Ice Stream C. Deviations between velocity vectors and the trajectories of relict-crevasse bands emanating from Ice Stream B should presently exceed approximately $20^{\circ}$ along down-stream parts of the trajectories.

\section{ACKNOWLEDGEMENTS}

This research was supported by the U.S. National Science Foundation (grant DPP 85-09451). I thank S.
Shabtaie, R.A. Bindschadler, K.C. Jezek, and M.A. Lange for helpful discussions and encouragement. K. Hutter and an anonymous referee suggested helpful improvements to the manuscript.

\section{REFERENCES}

Batchelor, G.K. 1967. An introduction to fluid dynamics. Cambridge, Cambridge University Press.

Jezek, K.C. 1984. Recent changes in the dynamic condition of the Ross Ice Shelf, Antarctica. J. Geophys. Res., 89(B1), 409-416.

MacAyeal, D.R. and V. Barcilon. 1988. Ice-shelf response to ice-stream discharge fluctuations: I. Unconfined ice tongues. J. Glaciol., 34(116), 121-127.

MacAyeal, D.R. and M.A. Lange. 1988. Ice-shelf response to ice-stream discharge fluctuations: II. Ideal rectangular ice shelf. J. Glaciol., 34(116), 128-135.

MacAyeal, D.R., R.A. Bindschadler, K.C. Jezek, and S. Shabtaie. 1988. Can relict crevasse plumes on Antarctic ice shelves reveal a history of ice-stream fluctuation? Ann. Glaciol., 11, 77-82.

Meier, M.F. and A. Post. 1969. What are glacier surges? Can. J. Earth Sci., 6(4, Pt. 2), 807-817.

Shabtaie, S. and C.R. Bentley. 1987. West Antarctic ice streams draining into the Ross Ice Shelf: configuration and mass balance. J. Geophys. Res., 92(B2), 1311-1336.

Stephenson, S.N. and R.A. Bindschadler. 1988. Observed velocity fluctuations on a major Antarctic ice stream. Nature, 334(6184), 695-697.

Thomas, R.H. and D.R. MacAyeal. 1982. Derived characteristics of the Ross Ice Shelf, Antarctica. $J$. Glaciol., 28(100), 397-412. 